\title{
Macro-Trends in Brazilian Environmental Education: some reflections based on Morin's theory of complexity
}

\author{
Macro-Tendencias en la Educación Ambiental Brasileña: algunas reflexiones basadas en \\ la teoría de la complejidad de Morin
}

\author{
Macrotendências na Educação Ambiental Brasileira: algumas reflexões baseadas na \\ teoria da complexidade de Morin
}

\author{
Juliana Mara Antonio ${ }^{1}$ \\ Adriana Massaê Kataoka² \\ Patrícia Neumann ${ }^{3}$
}

\begin{abstract}
Environmental education in Brazil is a multi, inter and transdisciplinary field of knowledge and its objective is the transformation of the relation between society and nature to the environmental sustainability connected to social justice. It presents different trends that change according to focus and speeches based on different epistemologies. There are different ways to concept and to practice environmental education. Among them, there are three macro-trends related to political pedagogical models: conservative, pragmatic and critical which ones have become important references to it. Then the objective of this paper is to think about macro-trends in environmental education supported by Complexity perspective considering that the environmental education is a field of knowledge in construction. For it, we present briefly the history of environmental education in Brazil, after we present three macro-trends and their more and less highlighted characteristics and we finally think about it. Environmental education under complexity perspective thinks about macro-trends based on principles from Morin's theory of complexity. It was possible to point some limitations and some potentialities in both macrotrends. We consider it is possible to increase the theoretical and methodological horizons of the environmental education when we incorporate multiple properties of reality. Besides, it allows to integrate characteristics of macro-tends that are fragmented.
\end{abstract}

Key-words: Complexity. Environmental Education. Edgar Morin.

\section{Resumen}

La educación embiental es un campo multi, inter y transdisciplinar del conocimiento que objetiva la transformación de la relación sociedad y naturaleza para la sustentabilidad ambiental aliada a la justicia social. Ella presenta varias tendencias que varían de acuerdo con los enfoques y discursos basados en diferentes epistemologías. Hay diferentes formas de concebir y practicar la educación ambiental. Entre ellos, hay tres macrotendencias relacionadas a modelos políticos y pedagógicos: la conservadora, la pragmática y la crítica, las cuales tienen tornado una importante referencia en la educación ambiental. Así, el objetivo de este artículo es pensar sobre las macrotendencias de la educación ambiental desde la perspectiva de la complexidad, una vece que la educación ambiental es un campo de conocimiento aún en construcción. Para eso, presentamos brevemente la historia de la educación ambiental nel Brasil, después las tres macrotendencias en sus aspectos más y menos evidenciados e, por fin, pensamos sobre tales aspectos. La educación ambiental, bajo la perspectiva

\footnotetext{
${ }^{1}$ Mestra em Ensino de Ciências e Matemática. Licenciada em Ciências Biológicas e Pedagogia. Membro do Núcleo de Educação Ambiental do Departamento de Ciências Biológicas - UNICENTRO. R. Simeão Varela de Sá, 03 - Vila Carli, Guarapuava - PR, 85040-080, Guarapuava, PR. julianamara85@ hotmail.com

2 Doutora e mestra em Ecologia e Recursos Naturais. Licenciada em Ciências Biológicas. Coordenadora do Núcleo de Educação Ambiental e docente do Departamento de Ciências Biológicas - UNICENTRO. R. Simeão Varela de Sá, 03 - Vila Carli, Guarapuava - PR, 85040-080, Guarapuava-PR. dri.kataoka@ hotmail.com

3 Mestra em Educação. Bacharel em Psicologia. Graduanda em Filosofia. Psicanalista em formação pela Sociedade Psicanalítica do Paraná. Membro do Núcleo de Educação Ambiental do Departamento de Ciências Biológicas e membro do Grupo Interdisciplinar de Estudo e Pesquisa em Desenvolvimento Humano e Educação do Departamento de Pedagogia na Universidade Estadual do Centro-Oeste - UNICENTRO. R. Simeão Varela de Sá, 03 - Vila Carli, Guarapuava - PR, 85040-080, Guarapuava, PR. souhumanista@gmail.com
} 
de la Complexidad, se ocupa de pensar las tres macrotendencias desde los principios de la teoría de la complejidad de Morin. El análisis evidenció algunas limitaciones en las tres macrotendencias, pero también algunas potencialidades en todas ellas. Consideramos que es posible expandir el horizonte teórico y metodológico de la educación ambiental cuando son incorporadas múltiples propriedades de la realidad. Además, esto permite integrar aspectos de las macrotendencias que se encuentran fragmentados.

Palabras-llave: Complexidad. Educación Ambiental. Edgar Morin.

\section{Resumo}

A educação ambiental é um campo multi, inter e transdisciplinar do conhecimento que visa à transformação da relação sociedade natureza em prol da sustentabilidade ambiental aliada a justiça social. Ela apresenta várias abordagens que variam de acordo com os enfoques e discursos adotados por diferentes pesquisadores, baseados em diferentes epistemologias. Há diferentes modos de conceber e praticar a educação ambiental. Entre eles, há três macrotendências relacionadas a modelos político-pedagógicos: a conservadora, a pragmática e a crítica, as quais têm se tornado uma importante referência na educação ambiental. Objetivamos, assim, pensar sobre as macrotendências da educação ambiental a partir da perspectiva da complexidade, uma vez que a educação ambiental é um campo do conhecimento ainda em construção. Para isto, apresentamos, brevemente, o histórico da educação ambiental no Brasil, depois apresentamos as três macrotendências e suas mais e menos destacadas características para, por fim, pensar sobre. A educação ambiental, sob a perceptiva da complexidade, volta-se a pensar as três macrotendências a partir dos princípios da teoria da complexidade de Morin. A análise permitiu evidenciar algumas limitações nas três macrotendências, bem como potencialidades em todas elas. Consideramos que é possível expandir o horizonte teórico e metodológico da educação ambiental quando se incorporam múltiplas propriedades da realidade. Além disso, isto permite integrar aspectos das macrotendências que se encontram fragmentados.

Palavras-chave: Complexidade. Educação Ambiental. Edgar Morin.

\section{Introduction}

Environmental education in Brazil encompasses several knowledge areas and aggregates a myriad of epistemological and methodological contributions. This broadspectrum nature can lead to generalization, confusion and even to theoretical and methodological superficiality. Despite being oriented by distinct fundamentals, a common ground is the criticism to the fragmentation of knowledge and, consequently, to the modern scientific paradigm regarded as limited to the understanding of contemporary environmental subjects.

Teixeira, Agudo and Tozoni-Reis (2018) discuss that such criticism is a consensus among environmental educators because "this starting point had already been widely considered by the most representative works in the area, which defend the importance of criticism to the model of science that developed throughout modernity" (p.48).

This criticism rests on the mechanistic paradigm that separates the relationship between human beings and nature. Amorin and Calloni (2015) indicate that this fragmented model of knowledge assimilation and edification has been carried out throughout history. In general, the status quo of the elaboration of knowledge in the West comprehensively followed the same assumptions of the scientific revolution of the 16th century and its subsequent developments that lasted until the 18th and 19th centuries. Since then, pedagogic trends that contrast the former emerged leading to a science crisis. To Santos (2006), the science crisis expression is not yet consolidated enough to transform its status quo though it has placed many secular uncertainties that fundament scientific research and the veracity of knowledge in the 21 st century under debate.

Alencastro and Souza-Lima (2015) explained that approaches to the interactions between humans and nature are distinct and somewhat conflicting due to the plurality of theoretical perspectives and interests in the field. According to the authors, an epistemology 
that "while being critical and vigilant philosophy, permanently and rigorously follows the process of construction of the environmental rationale that would thrust possible developments in the field of environmental education" is imperative (p.29). In this perspective, Gamboa (2007) highlights that the research in environmental education is emerging as a new epistemological field that aims to disrupt the gap between theory and practice along with the cartesian model.

The theory of complexity by Morin emerges in this scenario as an alternative to the modern paradigm of science and proposes the reconnection of knowledge without fully discarding the cartesian paradigm. The fundamentals of this theory lie in reconnecting the parts to understand the whole making the distinction of the parts without breaking them apart and retrieving their relationship with the complex. In addition, it seeks to connect the humanistic culture including arts, literature, poetry and philosophy with the scientific culture and natural sciences. Morin (2011) recognizes that the fragmentation of knowledge had led to advances in some areas but it also brought serious consequences. These last include the separation in which the human sciences "based on reflection can no longer employ sources of objective knowledge" and the scientific culture "based on the specialization of knowledge can no longer think and reflect on itself" (MORIN, 2011, p.76). In this context, we aimed to think over the macro-trends of environmental education based on text presented by Layrargues and Lima (2011) during the VI Research in Environmental Education Meeting, in Ribeirão Preto City, Brazil. Our reflexions were based on the perspective of complexity. To do so, we first present a brief history of environmental education in Brazil. Then we present the three macrotrends and their state of affairs to finally reflect on them under a complexity perspective.

\section{A brief Brazilian history and the macro-trends of environmental education}

Environmental education is a multi, inter and transdisciplinary field of study that aims to promote dialogs among different knowledge and to engender significant changes in society and address environmental issues. It arises together the necessity of changes regarding the conscious about the human relation with the environment and the objective of its preservation. The Conference of Stockholm in 1972 was its first milestone as an important politics on international scope. In Brazil, its national impact was when the SEMA (Environmental Special Secretary) was created in 1973 connected to the Interior Ministry that was responsible to promote the environmental management on country. Even if the Secretary was limited at that time because political factors that sometimes impeded its complete approach in environmental education, it was a very important as public politics.

It was complemented by the First Intergovernmental Conference of Environmental Education in 1977 in Tbilisi, Georgia. It was carried out by UNESCO as a support to the ONU Program to Environment (PNUMA) where there were deeper discussions which ones were started during the Conference of Stockholm. These deeper discussions deliberated about objectives and characteristics of environmental education and members were encouraged to elaborate strategies to add it in scholar education (DIAS, 2003).

The Brazilian government, as a way of implementation of environmental education in answer to actions promoted in Tbilisi, promulgated the Law 6.938/81 that institutes de National Policy of Environment and the National Council of Environment (CONAMA). This council created the Brazilian Institute of Environment (IBAMA) based on Brazilian Constitution from 1988, Chapter IV, article 225 about environment and related subjects connected as well to Law 7.735/89 (PARANÁ, 2000).

After, there was the ONU Conference about Environment and Development (RIO 92), the creation of Agenda 21 and a plan to human sustainability where the environmental debate emerged in a context of social questioning and it is part of a broader context related to the 
political, economic and social dimensions (CARVALHO, 2008). We can say the environment became relevant in Brazil after the institution of the Federal Law 6.938/81 (BRASIL, 1981) which established the National Policy of Environment. In its Article II, the environmental education is considered as a necessary tool to solve environmental problems and thus must be offered at all education levels (PARANÁ, 2008).

Further advancements on the environmental theme arose with the creation of the Ministry of Environment (MMA) and the National Environmental Education Program (PRONEA). Finally, the environmental education was institutionalized in 1999 with the creation of the National Policy of Environmental Education approved by the Law 9.795/99 which gave the Brazilian society the support needed to demand environmental education implementation. Then, it became an instrument of public policy and even made environmental education a required subject for basic education ${ }^{4}$.

The Article I of the Law 9.795/99 states that the environmental education is a process through which the individual and the collective construct social values, knowledge, skills, actions and capabilities towards environmental conservation and that environmental education is a common good to the population, essential to the quality of life and sustainability. The Article II reinforces the importance of environmental education as an essential and permanent component of national education and that it must be present and articulated at all levels and modalities of formal and informal educational process (BRASIL, 1999).

Since then, even with an emphasis on the interdisciplinary, educative and socioenvironmental conception of environment, the insertion of environmental education in schools have prioritized physical and biological aspects as if the ecological identity was distant from its social origins. Morais and Vieira (2017) presented the state of the art of environmental education research in schools based on the analysis of the work published in the annals of the XVI Encontro Paranaense de Educação Ambiental held in Curitiba, Brasil, in 2017. They found that despite the diversity of subjects and methodologies employed many studies still have a naturalistic view of environmental education associated with projects that promote school and local community visits to protected areas, rivers and forests and include pedagogical practices that target the contemplation of the physical and biological environment by focusing on local fauna and flora. Studies by Reigota (2006) and Sauvé (2005) remark that the naturalistic perception underpins the thought that human beings are only observers who contemplate and protect nature without the awareness of being part of it.

Loureiro (2012) explains that in environmental education conservative perspectives of education are resumed when the natural aspect of the environment is evidenced even if with creative methods. Such perspectives have long been put to question for establishing the dominance of science over popular knowledge, the interactions between politics and power and the solution found to save mankind through ethics and consciousness without considering the entire social organization.

Therefore, as a multi, inter and transdisciplinary field of research, the environmental education has several approaches that vary according to the focus and discourse adopted by different researchers based on distinct epistemologies. Each approach has its own characteristics and methods which may be common or fully distinct. This research area is yet under construction and thus aggregates contributions from different subjects. According to the specificity of the field of research, several authors have classified the environmental education

\footnotetext{
${ }^{4}$ The basic education in Brazil is chronologically organized in three parts: child education or pre-school ( 0 to 5 years), elementary school (6 to 14 years) and high school (15 to 17 years). Basic education also includes different modalities in order to attend different communities including indigenous education, special education, rural education, quilombola education, young and adult education and professional education. The environmental education permeates all stages and modalities.
} 
and prioritized specific aspects rather than others. Among them, the classification proposed by Sauvé (2005) and by Layrargues and Lima (2011) stand out.

Sauvé (2005) categorized fifteen EE lineages based on differences regarding how they conceive the environment, intention, main focus, examples and methodological application. These lineages are divided in two major groups according their chronology of emergence. The naturalist, the conservationist/recursive, resolutive, systemic and scientific are some of the oldest. The most recent are the holistic, the bioregionalist, the critical, ethnographic, sustainability, etc.

Layrargues and Lima (2011), on the other hand, classify the distinct ways to conceive and practice environmental education in three macro-trends related to political-pedagogical models: conservative, pragmatic and critical. Each of them contemplates a broad diversity of positions. The conservative macro-trend manifests through the conservationist, behaviorist, ecological alphabetization and self-awareness lineages of Sauvé (2005), which are distant from social, political and economical relationships and thus hardly lead to social changes. The conservative macro-trend is based on the fundamentals of ecology, praises the affective dimension in respect to nature, prioritizes individual transformation through training and changes without reflection camouflaging the alienation to the system and to the dominant paradigm. The conservative denomination of this macro-trend results from the focus on parts and isolates spheres instead of questioning the current society as a whole.

The pragmatic macro-trend relates to Sauvé's (2005) educational lineages of sustainable development and sustainable consumption. It is the demonstration of the environmentalism of results, contemporary pragmatism and market ecology that elapse from the neoliberal superiority established globally in the 80s and in the Brazilian scenario in the 90s during Fernando Collor presidency. It is rooted in post-war modes of production and consumption (LAYRARGUES and LIMA, 2011).

Finally, the critical macro-trend embraces the lineages of emancipatory, popular and transformative environmental education. It emphasizes the historical aspects of human-nature relationships, evidences the tenets that lead to the superiority of human beings and structures of accumulation of capital and seeks the political combat of socioenvironmental disparity and injustice. The Critical trend is opposite to the conservative and behavioral trends in the search to overcome the lack of context and politicize the environmental debate. It relates the different dimensions of sustainability and problematizes contradictions of developmental patterns. This macro-trend pursues the reflection and overcoming of dichotomies that result from the cartesian paradigm such as the dissociation between subject and object and nature and society, extending beyond biological, economical, sociological and political reductionisms (Ibid, 2011). Despite the interdisciplinarity related to knowledge reconnection being a core feature of this macro-trend since the first environmental education documents, it may present itself not only from a critical perspective but also with a conservative and pragmatic approach.

Furthermore, the National Curricular Guidelines of Environmental Education (Diretrizes Curriculares Nacionais de Educação Ambiental, Brasil, 2012) emphasizes the necessity of teacher training to integrate multiple areas and overcome knowledge fragmentation by including a discourse with distinct views, realities and perception of the world but it is important to highlight that it rarely occurs. Petraglia (1995) reports that student formation and school curricula eventually become fragmented since the majority does not prioritize a view of the whole or defend the interaction among different kinds of knowledge. The critic is valid because subjects are studied in isolation, out of context and thus unconnected from other elements as the psychological and spiritual ones.

Unconnected and out-of-context teaching jeopardize the formation of the individual as a whole, so methods and fundamentals that help reconnecting knowledge are needed. Morin (2000) brings humanistic aspects to education that are frequently forgotten. For instance, in 
his work 'Seven Complex Lessons in Education for the Future', he discusses the human condition, understanding, uncertainties and ethics and retakes the philosophical questions of knowledge, its limits, the importance of context and the feeling of belonging to this planet. Hence, it is in this context that we have been studying the principles and bases of the complexity theory as the epistemological foundation for such reconnection in environmental education.

\section{Macro-trends and complexity in environmental education}

There are several epistemological approaches that fundament environmental education practices regarding how they are thought about and executed (ALENCASTRO and SOUZALIMA, 2015). According them, environmental education demands a thorough analysis to articulate with its own principles, i.e., in conformity with the Law 9.975/1999, the humanist and democratic viewpoint, the perception of the environment as a whole, the pluralism of ideas and educational conceptions, the respect for diversity, the inter, multi and transdisciplinary methods, the relationship among ethics, education, work, and society and the constant critical evaluation.

Epistemological disputes and the distinct world views that lead to different ways to understand and practice environmental education are widespread in Brazil. These approaches are also classified differently and the macro-trends of Layrargues and Lima (2011), to some extent, evidence distinct ways to understand and practice environmental education. The three macro-trends were created by authors under a critical point of view so while they articulated macro-trends that were formerly apart within a critical perspective, we propose to reflect on them with a complexity perspective.

The conservative macro-trend was criticized for adopting a dichotomic society-nature conception (LAYRARGUES and LIMA, 2011). We agree with this criticism and according to Morin (2015) such dichotomies function as a shattering of reality that is the root of many socioenvironmental issues faced today. On the other hand, Layrargues and Lima (2011) mention that this macro-trend brings such a sensibility and affection towards the environment that it sensitizes and impacts the individual. However, they also regard this view as naive and romantic with little effect on the scope of social transformation (LAYRARGUES and LIMA, 2011).

Contrary to this criticism, we believe that the complexity of the individual that should be brought to the dialogue with the socio-political and ethical dimensions is retrieved in incorporating affection. The matter is not to limit oneself to the affective dimension but to consider it alongside the social and cognitive ones. Charlot (2006) reinforced the need to engender an intellectual mobility on the subject to promote the will to learn a new content (e.g. philosophical, historical, environmental) which is of great importance to broaden the critical view. This mobility is instigated by subjective and affective attributes.

We defend that the subjective/affective aspects are tightly bound to the intellectual/cognitive and social aspects of knowledge and to formal and informal learning. They are part of human complexity defended by Morin (2011) as an individual ${ }^{5}$ - species society triad. These terms are inseparable and lie in a recursive circuit ${ }^{6}$, i.e., the individual is part of the society and the society as a whole is present in the individual through language and culture. This same individual belongs to a species that carry a genetic heritage within each cell of the body. Therefore, the human being is simultaneously biological, psychological, spiritual, cultural, social and historical.

\footnotetext{
${ }^{5}$ We maintained the term "individual" throughout the text to maintain epistemological fidelity to the author.

${ }^{6}$ Process in which both the cause and effects (products) retroact on each other (Morin, 2011).
} 
The complex that is a human being is fragmented in the formal education, in the way of making science, and in the environmental education that values rational aspects regardless of others,such as the affective and spiritual ones. Some researchers in environmental education as Loureiro (2012), one of the authors of the Critical macro-trend, even mention the subjective and affective aspects in some occasions but they do so superficially. This superficiality is also applicable to the criticism that other macro-trends forget about the social-historical dimension. In the Critical macro-trend, a great significance is given to the social element while the individual is set aside in their singularity.

Notwithstanding, Batalloso (2012) defends the need to educate for sensibility and to invest in an education "with and for the heart" (pp. 163-164). In conducting sensitivity to environmental education it is possible to better understand affection and contribute to individual changes that can improve the relationship with other humans and with the environment. On the 'educate for sensibility', Morin (2015) states that the Eros, the constructive force of love, must be rescued. He points to the passion of an educator, conscious of their cultural role and responsibilities, for their mission and their students and explains that this is the love that guarantees an influence to change and improve reality.

However, there are several elements that demotivate the Eros such as undermining the prestige of the profession before society (MORIN, 2015). The demotivation escalates in the current socio-political context in which conservative forces that had always been present in the history of the country emerge in the attempt to subdue Fundamental Rights guaranteed by the 1988 Constitution including the liberty of expression within classrooms. Under the allegation that teachers are ideological doctrinaires, they believe that laws that prohibit the expression of a diversity of opinions and ideas are applicable. Hence, there are numerous factors that impair education from the demotivation of educators because the socio-political and economic scenario to the scorning of teachers by students, families, etc, in a country that, at least in part, does not recognize the relevance of education for social development and see it as an expense rather than an investment. For many people, it is better building more prisons than schools and good-quality education is still elite's privilege, i.e., the white bourgeois. The environmental education lies in this scenario so its insertion as an instrument to transform reality even with all difficulties and barriers is of primal importance.

The pragmatic macro-trend focuses on the punctual resolution of the environmental problem due to the environmental crisis aggravation that is often a consequence of unrestrained exploitation of natural resources. According to Loureiro (2018), this was one of the first trends to become institutionalized and publicly recognized in Brazil in the 70s as a solution of environmental problems found by the capitalist socioeconomic system. However, this approach only considers the biophysical nature of the environment instead of including the socioenvironmental understanding. This practical bias has been criticized for seeking cultural changes detached from social changes, i.e., it seeks superficial changes rather than problem causes thus requiring a thorough reflection.

The pragmatic approach is correlated with the conservationist/recursive and resolutive lineages of Sauvé (2005). The recursive lineage stands that the social function of education is to create an environmental consciousness. It advocates behaviours towards resource conservation with a written reference to the biological aspects whereas the resolutive lineage advocates for the development of abilities to solve environmental problems but with no concerns regarding awareness and reflection. In this perspective, Morin (2000) states that any educational action that fragment the understanding of a complex reality by separating theory from action is nothing but a discouraging, acritical and alienated practice.

This pragmatic perspective understands the environment apart from human beings as a finite natural resource supply. Thus, it promotes the fight to reduce waste without addressing the process that causes the problem, i.e., it searches transformation without questioning or 
understanding its fundamentals (LAYRARGUES and LIMA, 2011). According to Loureiro (2012), this type of pragmatism exteriorizes reality by leaving problem solution strictly to the technological realm and in the will to solve them it lessens the complexity of phenomena.

We agree with the criticism that the pragmatic macro-trend is insufficient because its actions are only aimed at the natural environment emphasizing technical perspectives. Although this proposal does not solve deeper issues for not considering a broad socio-political scope, its actions can be of great value if integrated to the whole. Each individual must be conscious of their responsibility regarding the world they inhabit - one of the focus of the pragmatic view - even if disconnected from the whole to some extent. Certainly, one cannot stand in the individual responsibility alone though it may represent the beginning of a broader consciousness.

Another criticism is made by Tristão (2007) who claims that pragmatic macro-trend is depoliticized because it does not consider the socio-historical perspective. However, it could only be considered as 'depoliticized' under a specific political perspective that requires accounting for social and historical aspects. Despite not considering these aspects, it is not depoliticized because every human action and every speech is political in the sense of generating change, directly or indirectly. The very fact that we recognize the limitations of the pragmatic proposal is already leading to change on account of motivation to think and search for new and better solutions. Moreover, if we understand that theories or practices are devoid of politics, we risk remaining without a deeper understanding of their influence on the constitution of society of what we can profit from it so, consequently, we cannot move forward in our own criticisms that would remain resumed on themselves year after year.

Finally, the Critical macro-trend places the environmental issues under a political, economic, social and historical context. Currently, it is considered the trend that has the best conditions to equip society to face the socio-environmental crisis (LOUREIRO, 2012; CARVALHO, 2008; LAYRARGUES and LIMA, 2011; TEIXEIRA, AGUDO and TOZONIREIS, 2018). Under a complexity perspective, its strength lies in the worth of the critical thought in relation to the social and the collective perspectives although it does not mention the self-criticism in the individual perspective. It lacks the appreciation of the individual especially regarding the affective and spiritual realms. In this context, the complexity expands and deepens the criticism of social elements to the self-criticism as well. It is primal to reflect on oneself and on aspects that are part of our culture such as the individualism, selfishness and competition as well as on their consequences for both the individual and the society. Including the self-criticism can significantly contribute to transforming the individual who opens up to a broader understanding of the social plane after acquiring a new understanding of their role in the world. Indeed, Morin (1998) discusses that the path to wisdom lies in the effort to understand rather than condemn, in the self-examination that embraces self-criticisms and in stimuli to acknowledge lying to oneself.

In summary, each macro-trend emphasizes some aspects instead of others, something that we understand as being part of the development of a knowledge area: the reality is multiple and is being constructed every moment. Indeed, it does not seem reasonable to expect that a single approach can embrace the complexity of life since each approach emerges to attend the specific demands at that time within the context of perception and understanding of individuals from that reality moment. Thus, all macro-trends contribute to some extent to environmental education whether for the point they stress or for those they do not. The highlights provided by each trend has to do with the problems we believe they can address.

The conservative macro-trend emphasizes the individual and their affective sensibility towards the environment but not the development of self-reflection and criticism. The pragmatic macro-trend also targets the individual though a technical individual who is able to solve problems in a practical manner rather than using affective sensibility, reflection or 
criticism. The Critical macro-trend aims at a reflective and critical individual that is mindful of the social but does not reflect on the self and, consequently, turns aside sensibility and affection. That is, each perspective has a distinct conception of the individual and features those aspects it believes will promote changes and solve problems. Although the ignored or less-emphasized aspects also tell us who the individual is, it does not mean these ones are less important.

We consider that the less prominent or ignored aspects of each macro-trend are related to Morin's (2000) 'blinding paradigms' in detecting 'error and illusion' from 'Seven Complex Lessons in Education for the Future'. This 'blindness' refers to the need to consider along the entire educational process the possibility of errors and illusions to occur when one aims at knowing something. In other words, the highlight of some elements rather than others has to do with the lens under which the world is being looked upon with the perspective of that moment in time and the influence of the individual and social components. Mistakes occur during the construction of knowledge about reality and they are part of the process so instead of excluding them they should be integrated into learning.

The complexity perspective brings the possibility to visualize the less prominent aspects of each trend and integrate them into a new theoretical and practical environmental education. In this context, Morin (2011) highlights the 'holographic principle' in which the whole is contained in the parts and each part is present in the whole simultaneously. Hence, we should neither be constrained to the whole (e.g., society and culture) nor to the individual (as if in isolation). We must address the individual, the society and their mutual influence where the individual must look outside (to the wold) and within (themselves) altogether: knowing the 'self' to comprehend the other and understand the world, to be with the self and with the other in the world plentifully. The complexity provides the opportunity to broaden and deepen the reflection and integration of multiple elements both individual and social. According to Morin (1998), the path to wisdom lies in the effort to understand rather than condemn, in the self-criticism, and in the stimuli to recognize the illusion to oneself to finally be free from it and enter in reality. While doing so Morin stresses the need to restore human constitutional aspects that were formerly neglected.

We see through the less-prominent aspects that the Critical macro trend points to the need to regenerate the affective and spiritual aspects whereas the other two point to the need to develop the critical and reflective aspects. The complexity view provides a foundation to reconnect these aspects that had been historically separated of which the environmental education is a reflection.

The question is: where does regeneration process begin? A starting point is the historical reflection of individuals and society since they way we look at nature (the planet) is historically and culturally constructed. Under this perspective, Morin (2000) discusses the 'pertinent knowledge'. History is extremely relevant in the educational processes because it brings knowledge to its local and global context placing it in the reality of individuals and making it relevant (Morin, 2000). The contextualization and reconstruction of something that was formerly established as the afore-mentioned knowledge fragmentation that underlies society is primal for a deeper understanding of socio-environmental issues. Reconstruction is only feasible when one revisits and rethinks what had already been constructed and that is the importance of historical reflection.

Morin (2000) ponders on the way the world is organized starting from the physical part and evidences our constitution as beings that belong to the universe where "disorder, order, and organization are [...] connected through interactions, in a solidary circuit, in which none of these terms can be conceived beyond the reference to the others and their placement in complex relations, i.e., complementary, competing, and antagonistic" (Ibid, 2000, pp. 7374). The interconnected and complex way of thinking, as defends Morin (2000), ruptures 
deterministic, fragmented and linear notions. Thus, the complex perspective shifts the thought to a broader notion of the environment and the individual.

Individual detachment from the planet and the forgetfulness of their interdependence were factors that contributed to escalate the socioenvironmental problem leading to the destruction of the environment and, therefore, of the individual. Silva and Calloni (2008) discuss that overexploitation of natural goods occurs because the detached individual believes nature is there to provide for their existence. Hence, the individual (founded in Modernity) believe they are capable to be free from the land and do not realize the distance from themselves and the others. In this context, to restore the relationship between nature and mankind, reflecting on interactions of contradiction and complementarity that are simultaneously established, is of primal importance. To do so is to make possible the emergence of a collective consciousness involved with change and with interactions of respect and solidarity providing the sense of belonging.

We stand that the complexity perspective provide the foundation to reconnect the neglected and historically disconnected aspects mentioned in the macro-trends, enhancing the perception of interdependence between beings and environment and individual and society. Morin (1977) evidences the importance of the connection of individual and society with spirit and planet: "I felt connected to the planetary patrimony, animated by the religion that connects, the rejection of what rejects, an infinite solidarity; that which the Tao names as the spirit of the valley: receives all the waters that flow in it" (Morin, 1977, p. 27). Here there is another fundamental and neglected aspect: the sentiment of belonging which is directly connected to individual spirituality. Spiritual in the sense of feeling part of something bigger, independently of what this something is. It is not specifically about religion but of earthly identity (MORIN, 1977).

Earthly identity is to feel part of the planet and the universe in such way that it leads to the understanding of differences and resemblances between humans and other species and to the growth of a sentiment of unity with them. This makes possible to change interactions in favour of all and to procure and to live relationships that are not based on exploitation and destruction.

If "being human is to have relationships - with other men and women, with themselves, and with the environment" (Makiuchi, 2006, p.29), it is imperative to remember that the environment need to be felt and thought about with alterity to understand that, even within all its diversity, they belong to it. In other words, earthly identity expresses a sentiment that transcends specific physical, psychological or cultural traits because, after all, we are all part of the planet and the cosmos. We are in the cosmos and the cosmos is in all of us. It is a conception of individual that is not superior or inferior to any other being whether it be animal, vegetal or inorganic but at the same level of importance.

The restoration and openness to diversity demand ethics and understanding. Yet, according to Silva and Calloni (2008), the 20th century is characterized by increased socioenvironmental crisis and therefore we must rethink actions through environmental education and create strategies to fight the secular rationale that pulls apart mankind/nature. Thinking about the mind (psychological/spiritual), brain (biological) and culture (social) triad as a complex network is one of the possibilities. As Morin (2002) states, the human species is shaped in culture and by culture. Human beings would not be without the biological, the brains that acts, understands and knows; without mind capable of consciousness, selfconsciousness and maker of ethical principles as well as without culture. Loureiro (2012) too defends that ethics presupposes culture and culture presupposes history and organization in groups. To Morin (2002), human gender ethics lies in the mutual movement between subjective and collective conciseness and in the feeling of being part of the individual/society/culture triad that make up the cosmos. 
Therefore, in this perspective one of the missions of environmental education is to help building a new ethics that shapes the democratic debate between theory and action and the way they are produced and organized by questioning values regarded as universal, absolute and unchangeable as well as questioning the error and illusions of the learning process, the type of individual we are trying to build and the consequences of every daily choice in the way of being in the world.

\section{Final remarks}

Given the greatness of the challenges and uncertainties of modernity and socioenvironmental problems, the fragmented and simplified thought is not enough; it is necessary to reconnect, to be open-mind and to listen, to develop sensibility and criticism. Under the complexity perspective, the environmental education reasons environmental subjects that embrace multiple reality properties and aims at the problematization of social practices and intersubjective interactions with organic and inorganic beings. This implies integrated knowledge acquisition and a contextualized and sensible interpretation of reality.

The complexity deconstructs the idea of omnipotence of the individual before nature which is a necessity of recent times. Our needs are distinct of those from Modernity which needed a science model that eliminated errors from the old method. In questioning everything, Descartes sought a foundational element, undoubtable which could sustain the investigation towards nature. Misconceptions of reality were the greatest concern of philosophers as Descartes and the hyperbolic questioning that led to the following dualisms was the path found in the attempt to understand the world and eliminate errors. To the moderns, mankind supremacy over nature was a necessity to breakup their submission to forces they did not understand as one of them the divinity so present in the medieval period. Currently, we need to rethink this hierarchical relationship between humans and nature that no longer attends to our needs.

Based on Morin, who emphasizes human complexity through the triad that involves species, individual and society, we aim to broaden the look beyond the three macro-trends. Each macro-trend neglects certain aspects in emphasizing others, eventually polarizing both individual and society by promoting a dichotomy, thus reproducing the fragmentation it so criticizes.

The complexity is an alternative to prevent dichotomies because it does not aim to provide ready answers for everything or to integrate everything into a generic whole. Contrariwise, the complexity demands theoretical depth in distinct perspectives, an effort to have clarity and distinction in transiting among them and to understand and respect their limitations and potentialities. In the case of complexity research and practice, the environmental education can emphasize one or more elements depending on the thematic and/or specific objective at that moment and context though it does not imply that it denies or excludes the less-emphasized aspects.

In Brazil, the environmental education began with the conservative macro-trend approach being later replaced by the pragmatic and critical ones and each approach has aspects that require integration instead of being ignored. For instance, we should integrate the affective and spiritual aspects of the conservative trend, make use of the practicality and rapid resolution of the pragmatic trend and add the critical and reflective aspects of the Critical trend. That is complexity.

Hence, we disagree that there must be an epistemological hegemony in environmental education and that a single theory or macro-trend is best to guide all practices. A complex environmental education is not substantiated in theoretical competition, it does not intend to be better than other perspectives and it does not aim to be the solution for all problems. 
Instead, its foundation is based on the proposal to integrate knowledge and this integration requires a conscious effort to listen to yourself and other beings, understanding them and respecting their individualities.

\section{References}

AMORIM, Filipi Vieira.; CALLONI, Humberto. Compreensões da Educação Ambiental: possibilidades e desafios do paradigma da complexidade. Revista de Ciências Humanas, v.47, n.2, pp. 272-288, 2013.

CARVALHO, Isabel Cristina de Moura. Educação Ambiental: a formação do sujeito ecológico. São Paulo: Cortez, 2008.

CHARLOT, Bernard A. pesquisa educacional entre conhecimentos, políticas e práticas: especificidades e desafios de uma área de saber. Revista Brasileira de educação, v.11, n.31, pp. 7-18, 2006.

DIAS, Genebaldo Freire. Educação Ambiental: princípios e práticas, 9ed. São Paulo: Gaia, 2013.

FLORIANI, Dimas. Educação ambiental e epistemologia: conhecimento e prática de fronteira ou uma disciplina a mais? Pesquisa em Educação Ambiental, v.4, n.2, pp. 191-202, 2009.

GAMBOA, Silvio Sánchez. Práticas de Pesquisa em Educação no Brasil: lugares, dinâmicas e conflitos. Pesquisa em Educação Ambiental, v.2, n.1, pp. 9-32, 2007.

LAYRARGUES, Philippe P.; LIMA, Gustavo F.C. Mapeando as macrotendências políticopedagógicas da educação ambiental contemporânea no Brasil. In: VI Encontro de Pesquisa em Educação Ambiental, Ribeirão Preto, 2011. Anais do VI Encontro Pesquisa em Educação Ambiental.

Disponível em: http://www.icmbio.gov.br/educacaoambiental/images/stories/biblioteca/educacao_ambiental/ Layrargues_e_Lima_-_Mapeando_as_macro-tend\%C3\%AAncias_da_EA.pdf. Acesso: maio de 2018.

Lei Federal 9795/99 de 27 de abril de 1999. Dispõe sobre a educação ambiental, institui a Política Nacional de Educação Ambiental e dá outras providências. Disponível em: http://www.planalto.gov.br>. Acesso: maio de 2018.

Lei $n^{\circ} 6.938$ de 31 de agosto de 1981. Dispõe sobre a Política Nacional do Meio Ambiente, seus fins e mecanismos de formulação e aplicação, e dá outras providências. Disponível em: http://www.planalto.gov.br. Acesso: maio de 2018.

LOUREIRO, Carlos Frederico Bernardo. Trajetória e Fundamentos da Educação Ambiental. São Paulo: Cortez, 2012.

MAKIUCHI, Maria de Fatima Rodrigues. Alteridade. In: FERRARO, J. (Org). Encontros e Caminhos: formação de educadoras (es) ambientais e coletivos educadores. Brasília: 2005, pp. 29-35. 
MORAES, Maria Cândida. Pensamento eco-sistêmico: educação, aprendizagem e cidadania no século XXI. Petrópolis: Vozes, 2008.

MORAIS, Josmaria L.; VIEIRA, Solange R. Educação Ambiental na Escola: reflexões sobre os trabalhos apresentados no XVI Encontro Paranaense de Educação Ambiental. REMEARevista Eletrônica do Mestrado em Educação Ambiental, Edição Especial, pp. 71-85, 2017.

MORIN, Edgar. O método 1: A natureza da natureza. Portugal, Publicações Europa-America, 1997.

MORIN, Edgar. Os Sete Saberes necessários à Educação do Futuro. São Paulo: Cortez, 2000.

MORIN, Edgar. Introdução ao pensamento complexo. Porto Alegre: Sulina, 2011.

MORIN, Edgar. Ensinar a viver: manifesto para mudar a educação. Porto Alegre: Sulina, 2015.

PARANÁ. Cadernos temáticos da diversidade: educação ambiental. Secretaria de Educação Departamento da Diversidade. Coordenação de Desafios Educacionais Contemporâneos, Curitiba, 2008.

PETRAGLIA, Isabel Cristina. Edgar Morin: educação e a complexidade do ser e do saber, 7ed. Petrópolis: Vozes, 1995.

REIGOTA, Marcos. O que é educação ambiental. São Paulo: Editora Brasiliense, 2006.

Resolução n. 2, de 15 de junho de 2012. Estabelece as Diretrizes Curriculares Nacionais para a Educação Ambiental. Diário Oficial da União, Brasília, n. 116, p. 70.

SANTOS, Boaventura de Souza. Um discurso sobre as ciências. Porto: Afrontamento, 2006.

SAUVÉ, Lucie. Uma cartografia das correntes de educação ambiental. In: SATO, M.; CARVAlHO, I. C. (Orgs.). Educação Ambiental: pesquisa e desafios. Porto Alegre: Artmed, 2005, pp. 17-44.

SILVA, Maria de Fátima Santos da.; CALLONI, Humberto. Educação ambiental e paradigma da complexidade: as concepções de homem e ambiente na discussão da crise socioambiental. Revista Didática Sistêmica, v. 8, p. 226-239, 2008.

SOUZA-LIMA, José Edmilson de.; ALENCASTRO, Mario Sergio Cunha. Educação Ambiental: breves considerações epistemológicas. Revista Meio Ambiente e Sustentabilidade, v. 8, n. 4, pp. 20-50, 2015.

TEIXEIRA, L.A.; AGUDO, Marcela de Moraes; TOZONI-REIS, Marília Freitas de Campos. Educação Ambiental Crítica e Pedagógica Histórico-Crítica: contribuições para a inserção da educação ambiental na educação escolar. In: RODRIGUES. D.G.; SAHEB, D. (Orgs.). Investigação em Educação Ambiental. Curitiba: CRV, 2018. 
TRISTÃO, Martha. A Educação Ambiental e os Contextos Formativos na Transição de Paradigmas. Reunião Anual da ANPEd, Caxambu, 2007. In: Anais da Reunião Anual da ANPEd. Disponível em: http://www.anped.org.br/biblioteca/item/educacao-ambiental-e-oscontextos-formativos-na-transicao-de-paradigmas. Acesso: maio de 2018.

UNESCO. Conferência de Estocolmo. Plano de Ação Mundial. In: DIAS, G.F. Educação Ambiental: princípios e práticas. São Paulo: Gaia, 1992. 